\title{
Correlation of Elevated Serum Alpha Feto-Protein Level with Mean Tumor Size in Hepatocellular Carcinoma
}

\author{
Muhammad Hanif1, Nabeeha Mobeen², Noor-ul-Huda³, Muhammad Abubakar Nagra4, Hafiz Amjad Hussain5, Umair Ahmed6, Amin Anjum \\ 1,7Department of Medicine, Faisalabad Medical University, Faisalabad-Pakistan, ${ }^{2,6}$ Department of Medicine, Allied Hospital, Faisalabad-Pakistan, ${ }^{3}$ Department of Medicine, Jinnah \\ Hospital, Lahore-Pakistan, ${ }^{4,5}$ Department of Medicine, DHQ Hospital, Faisalabad-Pakistan
}

\section{ABSTRACT}

Background: Correct diagnosis and staging of $\mathrm{HCC}$ are very vital regarding treatment and other decisions of management. We have several imaging modalities available with high sensitivity and specificity for diagnosis or staging of HCC but not so many biochemical tests for small or well differentiated HCC. Objective: Correlation of level of serum Alpha feto-protein with mean tumor size in hepatocellular carcinoma. Study Design: Descriptive, Crosssectional study. Settings: Departments of Medicine Allied Hospital and District Headquarters Hospital, Faisalabad Pakistan. Duration: $5^{\text {th }}$ November 2017 to $4^{\text {th }}$ May 2018. Methodology: A total of 40 patients of HCC and age 18-70 years of either gender were included. Pregnant, lactating women and patients having high levels of AFP from sources other than HCC were excluded. Serum levels of AFP were measured by same laboratory by taking blood samples and size of HCC on ultrasonography was obtained by same radiologist. Results: Mean age was $54.90 \pm 10.25$ years. Out of these 40 patients, $26(65.0 \%)$ were male and $14(35.0 \%)$ were females with male to female ratio of 1.9:1. Mean size of hepatocellular carcinoma was $6.44 \pm 3.40 \mathrm{~cm}$ and mean AFP levels were $3.0692 \mathrm{E} 3 \pm 6505.82 \mathrm{ng} / \mathrm{ml}$. Pearson Correlation coefficient between AFP levels and Size of HCC was found to be 0.152 with p-value of 0.349 . Conclusion: This study concluded that there is positive correlation between AFP levels and Size of HCC.

Keywords: Hepatocellular carcinoma, Tumor size, AFP levels.

Corresponding Author

Submitted for Publication: 10-08-2020

Dr. Muhammad Hanif, Associate Professor, Department of Medicine, Faisalabad Medical University, Faisalabad-Pakistan.

Email: drhanifnagra@hotmail.com

Mean Tumor Size in Hepatocellular Carcinoma. APMC 2020;14(3):281-5.

DOI: 10.29054/APMC/2020.987

\section{INTRODUCTION}

Liver is a vital organ of the body and common site for tumors which may be benign or malignant primary or secondary. Primary liver cancer is the fifth most common malignancy in men and the eighth in women worldwide. In 2000, it was estimated that there were about 564,000 new cases of liver cancer worldwide, and a similar number of patients died as a result of this disease. ${ }^{1}$

Any lesion found in liver of a known malignant patients needs further workup as metastatic spread is very common in liver and such lesions are present in approximately $7-25 \%$ of population. ${ }^{2}$ Malignant lesion may be hepatocellular carcinoma which is primary malignancy of liver or they may be metastatic from other organs like primary cancer in colon. Benign lesions of liver may be liver cysts (simple, as well as polycystic liver disease), hemangiomas, focal nodular hyperplasias, adenoma and sarcoidosis. Fatty liver and liver cirrhosis may also result in diffused liver lesions. Simple cysts can be present in liver as fluid filled cavity causing no symptoms, but in polycystic liver disease there are many cysts of variable shapes and sizes, present throughout the organ. It may be asymptomatic in some persons but it can cause abdominal discomfort in others. ${ }^{3}$

Most common primary malignancy of liver is hepatocellular carcinoma (HCC). Risk factors of HCC are hepatitis B and C virus infections, dietary intake of aflatoxins and drinking contaminated water in the rural areas. Although hepatitis B virus
(HBV) is main factor for $\mathrm{HCC}$ in many Asian Pacific countries, hepatitis $\mathrm{C}$ virus $(\mathrm{HCV})$ is responsible for most cases of $\mathrm{HCC}$ in Pakistan. ${ }^{4,5}$

Pakistan has Anti HCV antibody in about $4.8 \%$ of general population while HBS antigen is positive in $2.5 \%$ of about 200 million general population. High contamination rates with aflatoxin in Pakistan is also responsible for liver carcinogenesis. The age-standardized rate of HCC in Pakistan is about 7.6 per 100,000 persons per year for males and 2.8 for females. At the time of diagnosis, $\mathrm{HCC}$ is at advanced stage of disease in most of patients and is usually associated with liver cirrhosis. The main objective of treatment is to slow tumor growth at advance stage of disease as no permanent medical cure is available. While in well developed countries $30 \%$ of patients are present in early stages of hepatocellular carcinoma. ${ }^{6}$

Correct diagnosis and staging of $\mathrm{HCC}$ are vital in deciding treatment modality. A variety of imaging techniques can be used for identification and staging of HCC. Some imaging techniques have high sensitivity and specificity for diagnosis or staging of HCC but its results are not good for small or well differentiated $\mathrm{HCC}^{7}$

Main tools which are widely used to diagnose liver cancer at early stage are ultrasound of liver or alpha-fetoprotein which are often combined together. A study conducted in Jinnah Postgraduate Medical Centre Karachi showed there was a significant correlation of mean serum AFP level with mean 
tumor size in hepatocellular carcinoma. Resection or transplant of liver can be done in early stages of liver with better outcomes. ${ }^{8,9}$

The purpose of my study was to determine if there is any significant correlation between the size of HCC and level of alpha fetoprotein and if AFP level can be used to differentiate between early and advance stage, on the basis of which proper treatment strategy can be planned.

The objective of the study was to determine the correlation of serum Alpha feto-protein level with mean tumor size in hepatocellular carcinoma.

Operational Definitions:

Mean Alphafeto Protein (AFP): Mean Alpha feto protein level was measured as given by same laboratory.

Mean Tumor Size: Tumor size was measured on ultrasonography done by same radiologist, as the size of focal lesion seen.

Hepatocellular Carcinoma: Hepatocellular carcinoma is a focal lesion in liver originating from hepatocytes not a secondary from any other organ.

\section{METHODOLOGY}

Study Design: Descriptive, Cross-sectional study.

Settings: Departments of Medicine Allied Hospital and District Headquarters Hospital, Faisalabad Pakistan.

Duration: $5^{\text {th }}$ November 2017 to $4^{\text {th }}$ May 2018.

Sample Technique: Non-probability, consecutive sampling.

Sample Size: By using correlation sample size calculator; $r=0.472^{1}$, Type1 error $=5 \%$, Type 2 error $=10 \%$, Confidence level $=95 \%$, Sample size $=40$

Inclusion Criteria: Both males and females in between 18-70 years with diagnosed cases of HCC.

Exclusion Criteria: Patients having metastasis, pregnant females, lactating females and patients having high levels of AFP from sources other than HCC e.g. ataxia telangiectasia, tumors of ovary or testes were excluded from the study.

Data Collection Procedure: After Approved from ethical committee and taking informed consent, Patient fulfilling the inclusion criteria was enrolled in the study. Serum levels of AFP were measured by same laboratory by taking blood samples and size of HCC on ultrasonography was obtained by same radiologist. Data was collected using a standardized Performa by principal investigator. Follow up was insured by contacting the patient through telephone.

Data Analysis Procedure: All the collected information was transferred to SPSS Version 20 to be analyzed accordingly. Mean and standard deviation were calculated for all quantitative variables like age, serum AFP level and tumor size. Frequency and percentage were calculated for all qualitative variables like gender. Pearson's Correlation was applied to correlate elevated serum AFP level and tumor size. Effect modifiers like age and gender were controlled by stratification. Post stratification Pearson's correlation was applied. P-value $\leq 5$ was taken as significant.
RESULTS

Age range in this study was from 18 to 70 years with mean age of $54.90 \pm 10.25$ years. Majority of the patients $30(75.0 \%)$ were between 46 to 70 years of age as shown in Table 1 .

Table 1: Age distribution for patients $(n=140)$

\begin{tabular}{|c|c|c|}
\hline Age (In years) & No. of Patients & Percentage \% \\
\hline $18-45$ & 10 & 25.0 \\
\hline $46-70$ & 30 & 75.0 \\
\hline Total & 40 & 100.0 \\
\hline
\end{tabular}

Mean \pm SD $=54.90 \pm 10.25$ years

Out of these 40 patients, $26(65.0 \%)$ were male and $14(35.0 \%)$ were females with male to female ratio of $1.9: 1$ as shown in Figure 1.

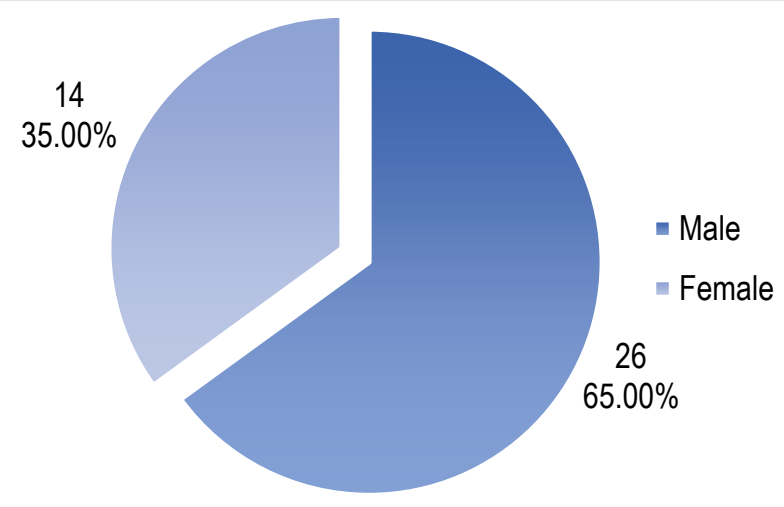

Figure 1: Gender distribution of the patients $(n=40)$

Mean size of hepatocellular carcinoma was $6.44 \pm 3.40 \mathrm{~cm}$ and mean AFP levels were $3.0692 \mathrm{E} 3 \pm 6505.82 \mathrm{ng} / \mathrm{ml}$ as shown in Table 2. Pearson Correlation coefficient between AFP levels and Size of HCC is shown in Table 2 and was found to be 0.152 with $p$-value of 0.349 .

Table 2: Correlation between AFP levels and size of HCC

\begin{tabular}{|c|c|c|c|c|c|}
\hline & $\mathbf{n}$ & Minimum & Maximum & Mean & Std. Deviation \\
\hline AFP $(\mathbf{n g} / \mathrm{ml})$ & 40 & 2.13 & 25830.00 & $3.0692 \mathrm{E} 3$ & 6505.82 \\
\hline HCC $(\mathbf{c m})$ & 40 & 1.20 & 17.50 & 6.44 & 3.40 \\
\hline
\end{tabular}

\begin{tabular}{|c|l|c|c|}
\hline \multicolumn{2}{|l|}{ Correlations } & HCC & AFP \\
\hline \multirow{3}{*}{ AFP (ng/ml) } & Pearson Correlation & 1 & 0.152 \\
\cline { 2 - 4 } & Sig. (2-tailed) & & 0.349 \\
\cline { 2 - 4 } & $\mathrm{n}$ & 40 & 40 \\
\hline \multirow{3}{*}{ HCC (cm) } & Pearson Correlation & 0.152 & 1 \\
\cline { 2 - 4 } & Sig. (2-tailed) & 0.349 & \\
\cline { 2 - 5 } & $\mathrm{n}$ & 40 & 40 \\
\hline
\end{tabular}


Stratification of correlation between AFP levels and Size of HCC with respect to age groups is shown in Table $3 \& 4$.

Table 3: Stratification of AFP levels and size of HCC

\begin{tabular}{|c|c|c|c|}
\hline & Mean & Std. Deviation & $\mathbf{n}$ \\
\hline HCC & $3.6077 \mathrm{E} 3$ & 7904.03 & 10 \\
\hline AFP & 5.11 & 1.75 & 10 \\
\hline \multicolumn{4}{|c|}{ age group $=18-45$} \\
\hline
\end{tabular}

\begin{tabular}{|c|l|c|c|}
\hline \multicolumn{2}{|c|}{ Correlations $^{\mathrm{a}}$} & VAR00005 & VAR00006 \\
\hline \multirow{3}{*}{ AFP } & Pearson Correlation & 0.322 & 1 \\
\cline { 2 - 4 } & Sig. (2-tailed) & 0.364 & \\
\cline { 2 - 4 } & $\mathbf{N}$ & 10 & 10 \\
\hline \multirow{3}{*}{ HCC } & Pearson Correlation & -0.195 & 0.202 \\
\cline { 2 - 4 } & Sig. (2-tailed) & 0.589 & 0.576 \\
\cline { 2 - 4 } & $\mathbf{N}$ & 10 & 10 \\
\hline
\end{tabular}

Table 4: Stratification of AFP levels and size of HCC

\begin{tabular}{|c|c|c|c|}
\hline & Mean & Std. Deviation & N \\
\hline AFP & 2.8897 E3 & 6115.48 & 30 \\
\hline HCC & 6.8 & 3.71 & 30 \\
\hline \multicolumn{4}{|c|}{ age group $=46-70$} \\
\hline
\end{tabular}

\begin{tabular}{|c|l|c|c|}
\hline \multicolumn{2}{|c|}{ Correlations $^{\text {a }}$} & VAR00005 & VAR00006 \\
\hline \multirow{4}{*}{ AFP } & Pearson Correlation & .002 & 1 \\
\cline { 2 - 4 } & Sig. (2-tailed) & .991 & \\
\cline { 2 - 4 } & $\mathbf{N}$ & 30 & 30 \\
\hline \multirow{3}{*}{ HCC } & Pearson Correlation & -.111 & .176 \\
\cline { 2 - 4 } & Sig. (2-tailed) & .559 & .353 \\
\cline { 2 - 4 } & $\mathbf{N}$ & 30 & 30 \\
\hline
\end{tabular}

Table $5 \& 6$ have shown the stratification of correlation between AFP levels and Size of HCC with respect to gender.

Table 5: Stratification of male gender with respect to AFP levels and size of HCC

\begin{tabular}{|c|c|c|c|}
\hline & Mean & Std. Deviation & N \\
\hline AFP & $2.9758 \mathrm{E} 3$ & 6933.10 & 26 \\
\hline HCC & 6.29 & 3.13 & 26 \\
\hline \multicolumn{3}{|l}{} \\
\hline
\end{tabular}

\begin{tabular}{|c|c|c|c|}
\hline \multicolumn{2}{|c|}{ Correlations $^{\mathrm{a}}$} & VAR00005 & VAR00006 \\
\hline \multirow{3}{*}{ AFP } & Pearson Correlation $^{\prime}$ & 0.004 & 1 \\
\cline { 2 - 4 } & Sig. (2-tailed) & 0.984 & \\
\cline { 2 - 4 } & $\mathbf{N}$ & 26 & 26 \\
\hline \multirow{3}{*}{ HCC } & Pearson Correlation & -0.209 & 0.123 \\
\cline { 2 - 4 } & Sig. (2-tailed) & 0.306 & 0.550 \\
\cline { 2 - 4 } & $\mathbf{N}$ & 26 & 26 \\
\hline
\end{tabular}
levels and Size of HCC

\begin{tabular}{|c|c|c|c|}
\hline & Mean & Std. Deviation & N \\
\hline AFP & $3.2426 \mathrm{E} 3$ & 5872.74 & 14 \\
\hline HCC & 6.70 & 3.96 & 14 \\
\hline
\end{tabular}

\begin{tabular}{|c|c|c|c|}
\hline \multicolumn{2}{|c|}{ Correlations $^{\mathrm{a}}$} & VAR00005 & VAR00006 \\
\hline \multirow{3}{*}{ AFP } & Pearson Correlation & -0.360 & 1 \\
\hline & Sig. (2-tailed) & 0.206 & \\
\hline & $\mathrm{N}$ & 14 & 14 \\
\hline \multirow{3}{*}{$\mathrm{HCC}$} & Pearson Correlation & -0.207 & 0.210 \\
\hline & Sig. (2-tailed) & 0.478 & 0.471 \\
\hline & $\mathrm{N}$ & 14 & 14 \\
\hline
\end{tabular}

\section{DISCUSSION}

In-spite of having multiple researches to find new markers for HCC diagnosis, serum AFP is still considered to be the most important marker. Although serum AFP levels are high in patients with $\mathrm{HCC}$, may be low in some patients. Interestingly, the level may be high in non-cancerous cirrhotic patients ${ }^{10,11}$ in order to predict presence of liver cancer in cirrhotic patient or chronic viral hepatitis $B$ or $C$ patients, AFP is still the only marker to be advised. ${ }^{12,13}$ Its level has both diagnostic and prognostic value. Because of low cost, it is also valuable marker for postoperative HCC reoccurrence and metastasis. ${ }^{14}$ Although its higher levels are associated with portal vein tumor thrombosis, involvement of both lobes of liver, larger tumor size and massive involvement ${ }^{12}$ there is no consistent correlation between its level, tumor size and metastasis. ${ }^{16}$

I have conducted this study to determine the correlation of serum Alpha feto-protein level with mean tumor size in hepatocellular carcinoma. Age range in this study was from 18 to 70 years with mean age of $54.90 \pm 10.25$ years. Majority of the patients $30(75.0 \%)$ were between 46 to 70 years of age. Out of these 40 patients, 26 (65.0\%) were male and 14 (35.0\%) were females with male to female ratio of 1.9:1. Mean size of hepatocellular carcinoma was $6.44 \pm 3.40 \mathrm{~cm}$ and mean AFP levels were $3.0692 \mathrm{E} 3 \pm 6505.82 \mathrm{ng} / \mathrm{ml}$. Pearson Correlation coefficient between AFP levels and Size of HCC was found to be 0.152 with $p$-value of 0.349 . In a cross-sectional analytical study, ${ }^{9}$ review of the clinical data of 98 patients male $69(70.4 \%)$ and female were $29(29.6 \%)$ with mean age of $53.89 \pm 12.511$ ranging from 32 to 82 years was done. Of these there were 22 $(22.4 \%), 25(25.5 \%), 51(52 \%)$ cases in group 1, 2, 3 respectively. While in tumor size groups, $17(17.3 \%)$ were in group A, 35 (35.7\%) in group B and $46(46.9 \%)$ in group C. There was a significant correlation of serum AFP level with tumor size in hepatocellular carcinoma. $(r=0.472,0.0001) .{ }^{9}$

During fetal development liver and yolk sac are the main source of AFP production and after birth, its levels rapidly diminishes with only trace amount left by second year. Although, its level primary indicate $\mathrm{HCC}$, it may also be detectable in other malignancies. In patients with clinical correlation to HCC, a confirmatory tissue diagnosis is highly likely with AFP levels 
greater than $400 \mathrm{ng} / \mathrm{ml} .{ }^{17} \mathrm{~A}$ normal level of AFP with clinical evidence of $\mathrm{HCC}$ dose not rule out its diagnosis but it is used most specifically to check the efficacy of treatment of HCC as follow up marker.

Recently, there has been decrease in the important of AFP, regardless, there is proof which validates AFP as good prognostic marker in treated HCC patients. In addition, patients having more than $1000 \mathrm{ng} / \mathrm{ml}$ levels of AFP are considered poor candidates for liver transplantation. ${ }^{18}$ Thus, AFP level may also be used as criteria for transplant candidate selection ${ }^{19}$ In those receiving locoregional treatments like radioembolization by yttrium-99 or trans-arterial embolization (TACE) , a fall of more than $50 \%$ AFP indicated good outcomes of therapy, longer survival rate and timely detection of progression. ${ }^{20} \mathrm{As}$ discussed earlier and increased post treatment AFP level indicates recurrence of $\mathrm{HCC}$ which is also highlighted by the guideline of American Association for the study of liver diseases (AASLD). ${ }^{21}$ However, efficacy of AFP monitoring is controversial and varies, based on etiology of CLD in patients with HCC. ${ }^{21}$ Evaluation of serum AFP may also be due to underline necrosis and inflammation ${ }^{22}$ similarly AFP has been seen as predictor of postsurgical tumor recurrence and patient survival. ${ }^{23-27}$

after observing its strong correlation between AFP values and micro vascular invasions and tumor dimensions. ${ }^{28}$

In fact, tumor activity and vascular invasion correlates with increased AFP levels which is further evident by a link between $\mathrm{HCC}$ cell distribution in blood and AFP mRNA. ${ }^{29-30}$

Recent studies of 6817 US patients, AFP level before surgery is considered to be a strong variable as patient selection for liver transplantation. ${ }^{23}$ Similar studies in Italy shows a raised AFP level before liver transplantation as independent risk factor for recurrence of $\mathrm{HCC}^{24}$

Debates are going on regarding AFP threshold values to be used with proposed cut off values at $210,400 \& 1000 \mathrm{ng} / \mathrm{ml} .^{31-32}$ with no definitive international levels. As suggested by two studies from France and Canada, post LT recurrence of HCC is related to velocity at which AFP increases.

However, this new indicator and its proposed cut off value (15 to $50 \mathrm{ng} / \mathrm{ml} / \mathrm{month}$ ) need to be confirmed.

\section{CONCLUSION}

This study concluded that there is positive correlation between AFP levels and Size of HCC. So, we recommend that, monitoring of AFP levels in cirrhosis is useful in early detection of $\mathrm{HCC}$ and in monitoring of recurrence after treatment in order to reduce the morbidity and mortality of these particular patients.

\section{LIMITATIONS}

This was a small sample size and single center study.

\section{SUGGESTIONS / RECOMMENDATIONS}

Further large sample size multicenter studies should be done to assess the more significance of this marker.

\section{CONFLICT OF INTEREST / DISCLOSURE}

None.

\section{ACKNOWLEDGEMENTS}

We are thankful to our colleagues for their guidelines and support.

\section{REFERENCES}

1. Bosch FX, Ribes J, Díaz M, Cléries R. Primary liver cancer: worldwide incidence and trends. Gastroenterol. 2004;127:5-16.

2. Assy N, Nasser G, Djibre A, Beniashvili Z, Elias S, Zidan J. Characteristics of common solid liver lesions and recommendations for diagnostic workup. World J Gastroenterol 2009;15:3217-27.

3. Rubin RA, Mithchell DG. Evaluation of the solid hepatic mass. Med Clin North Am. 1996;80:907-28.

4. Butt AS, Hamid S, Wadalawala AA, Ghufran M, Javed AA, Farooq O, et al. Hepatocellular carcinoma in Native South Asian Pakistani population; trends, clinico-pathological characteristics and differences in viral marker negative and viral-hepatocellular carcinoma. BMC Res Notes 2013; 6:137

5. Butt AS, Abbas Z, Jafri W. Hepatocellular carcinoma in Pakistan: where do we stand? Hepat Mon 2012;12:e6023.

6. Weis S, Franke A, Mössner J, Jakobsen JC, Schoppmeyer K. Radiofrequency (thermal) ablation versus no intervention or other interventions for hepatocellular carcinoma. Cochrane Database of Systematic Reviews 2013, Issue 12. Art. No.: CD003046. DOI: 10.1002/14651858.CD003046.pub3. Link

7. Chou R, Cuevas C, Fu R, Devine B, Wasson N, Ginsburg A, Zakher B, Pappas M, Graham E, Sullivan S. Imaging Techniques for the Diagnosis and Staging of Hepatocellular Carcinoma. Comparative Effectiveness Review No. 143. (Prepared by the Pacific Northwest Evidence-based Practice Center under Contract No. 290-2012-00014-I.) AHRQ Publication No. 14(15)EHC048-EF. Rockville, MD: Agency for Healthcare Research and Quality; October 2014.

8. Aghoram R, Cai P, Dickinson JA. Alpha-foetoprotein and/or liver ultrasonography for screening of hepatocellular carcinoma in patients with chronic hepatitis B. Cochrane Database of Systematic Reviews 2012, Issue 9. Art. No.: CD002799. DOI: 10.1002/14651858.CD002799.

9. Abbasi A, Bhutto AR, Butt N, Munir SM. J Pak Med Assoc. 2012 Jan;62(1):33-6.

10. Tateishi R, Yoshida H, Matsuyama Y, Mine N, Kondo Y, Omata M. Diagnostic accuracy of tumor markers for hepatocellular carcinoma: a systematic review. Hepatol Int. 2008;2: 17-30.

11. Snowberger N, Chinnakotla S, Lepe RM, Peattie J, Goldstein R, Klintmalm GB, Davis GL. Alpha fetoprotein, ultrasound, computerized tomography and magnetic resonance imaging for detection of hepatocellular carcinoma in patients with advanced cirrhosis. Aliment Pharmacol Ther. 2007;26: 1187-1194.

12. Baig JA, Alam JM, Mahmood SR, Baig M, Shaheen R, Sultana I, Waheed A. Hepatocellular carcinoma (HCC) and diagnostic significance of A-fetoprotein (AFP). J Ayub Med Coll Abbottabad. 2009;21: 72-75.

13. Lee HY, Jung JH, Kang YS, Kim YS, Moon HS, Park KO, et al. Clinical significance of transiently elevated serum AFP level in developing hepatocellular carcinoma in HBsAg positive-liver cirrhosis [Article in Korean]. Korean J Gastroenterol. 2004;43:252-259.

14. Chang SK, Hlaing WW, Yu RQ, Lee TW, Ganpathi IS, Madhavan KK. Value of alpha-foetoprotein for screening of recurrence in hepatocellular carcinoma post resection. Singapore Med J. 2012;53: 32-35. 
15. Tangkijvanich $P$, Anukulkarnkusol $N$, Suwangool $P$, Lertmaharit S, Hanvivatvong O, Kullavanijaya P, Poovorawan Y. Clinical characteristics and prognosis of hepatocellular carcinoma: analysis based on serum alpha-fetoprotein levels. J Clin Gastroenterol. 2000;31: 302-308.

16. Qin LX, Tang ZY. The prognostic significance of clinical and pathological features in hepatocellular carcinoma. World $\mathrm{J}$ Gastroenterol. 2002;8: 193-199.

17. Chen DS, Sung JL. Hepatitis B virus infection in Taiwan. N Engl JMed 1977;297:668-9.

18. Hakeem AR, Young RS, Marangoni G, Lodge JP, Prasad KR. Systematic review: the prognostic role of alpha-fetoprotein following liver transplantation for hepatocellular carcinoma. Aliment Pharmacol Ther 2012; 35: 987-999. pmid:22429190

19. Toso C, Meeberg G, Hernandez-Alejandro R, Dufour JF, Marotta $P$, Majno $P$, et al. Total tumor volume and alpha-fetoprotein for selection of transplant candidates with hepatocellular carcinoma: A prospective validation. Hepatology 2015; 62: 158-165.

20. Riaz A, Ryu RK, Kulik LM, Mulcahy MF, Lewandowski RJ, Minocha J, et al. Alpha-fetoprotein response after locoregional therapy for hepatocellular carcinoma: oncologic marker of radiologic response, progression, and survival. J Clin Oncol 2009; 27:5734-5742

21. Lee HS, Chung YH, Kim CY. Specificities of serum alphafetoprotein in $\mathrm{HBsAg}+$ and $\mathrm{HBsAg}$ - patients in the diagnosis of hepatocellular carcinoma. Hepatology 1991; 14: 68-72.

22. Richardson P, Duan Z, Kramer J, Davila JA, Tyson GL, El-Serag $\mathrm{HB}$. Determinants of serum alpha-fetoprotein levels in hepatitis C-infected patients. Clin Gastroenterol Hepatol 2012; 10: 428433.

23. Merani $S$, Majno $P$, Kneteman NM. The impact of waiting list alpha-fetoprotein changes on the outcome of liver transplant for hepatocellular carcinoma. J Hepatol. 2011;55:814-819, 2011.

24. Lai Q, Avolio AW, Manzia TM. Role of alpha-fetoprotein in selection of patients with hepatocellular carcinoma waiting for liver transplantation: must we reconsider it? Int J Biol Markers. 2011;26:153-159, 2011.

25. Tsai MC, Wang $\mathrm{JH}$, Hung $\mathrm{CH}$. Favorable a-fetoprotein decrease as a prognostic surrogate in patients with hepatocellular carcinoma after radiofrequency ablation. J Gastroenterol Hepatol. 2010;25:605-612.

26. Shao $Y Y$, Lin ZZ. Early alpha-fetoprotein response predicts treatment efficacy of antiangiogenic systemic therapy in patients with advanced hepatocellular carcinoma. Cancer. 2010;116:4590-4596.

27. Chan SL, Mo KEF. New utility of an old marker: serial afetoprotein measurement in predicting radiologic response and survival of patients with hepatocellular carcinoma undergoing systemic chemotherapy. J Clin Oncol. 2009;27:446-452.

28. Lai Q, Merli M, Ginanni Corradini S. Predictive factors of recurrence of hepatocellular carcinoma after liver transplantation: a multivariate analysis. Transplantation Proceedings. 2009;41:1306-1309.

29. Cillo U, Vitale A, Navaglia F. Role of blood AFP mRNA and tumor grade in the preoperative prognostic evaluation of patients with hepatocellular carcinoma. World J Gastroenterol. 2005;11:6920 6925.

30. lavarone $M$, Lampertico $P$, Ronchi $G$. A prospective study of blood alpha-fetoprotein messenger $\mathrm{RNa}$ as a predictor of hepatocellular carcinoma in patients with cirrhosis. J Viral Hepatitis. 2003;10:423-426.
31. Toso C, Asthana S, Bigam DL. Reassessing selection criteria prior to liver transplantation for hepatocellular carcinoma utilizing the scientific registry of transplant recipients database. Hepatol. 2009;49:832-838.

32. Pomfret EA, Washburn K, Wald C. Report of a national conference on liver allocation in patients with hepatocellular carcinoma in the United States. Liver Transplantation. 2010;16:262-278.

33. Vibert E, Azoulay D, Hoti E. Progression of alphafetoprotein before liver transplantation for hepatocellular carcinoma in cirrhotic patients: a critical factor. Am J Transplant. 2010;10:129_ 137.

34. Han K, Tzimas GN, Barkun JS. Preoperative alpha-fetoprotein slope is predictive of hepatocellular carcinoma recurrence after liver transplantation. Canadian J Gastroenterol. 2007;21:39-45.

\section{AUTHORSHIP CONTRIBUTION}

\begin{tabular}{|l|l|}
\hline $\begin{array}{l}\text { Dr. Muhammad Hanif } \\
\text { Associate Professor of Medicine, } \\
\text { Faisalabad Medical University, } \\
\text { Faisalabad Pakistan }\end{array}$ & $\begin{array}{l}\text { Manuscript designing, Data } \\
\text { Analysis }\end{array}$ \\
\hline $\begin{array}{l}\text { Dr. Nabeeha Mobeen } \\
\text { Post Graduate Resident, } \\
\text { Department of Medicine Allied } \\
\text { Hospital, Faisalabad Pakistan }\end{array}$ & $\begin{array}{l}\text { Statistical Analysis, Data } \\
\text { Collection }\end{array}$ \\
\hline $\begin{array}{l}\text { Dr. Noor-ul-Huda } \\
\text { House Officer, Medicine } \\
\text { Jinnah Hospital, Lahore Pakistan }\end{array}$ & Review of Literature \\
\hline $\begin{array}{l}\text { Dr. Muhammad Abubakar Nagra } \\
\text { Post Graduate Resident, } \\
\text { Department of Medicine, DHQ } \\
\text { Hospital, Faisalabad Pakistan }\end{array}$ & $\begin{array}{l}\text { References Writing, Composition } \\
\text { of Discussion, }\end{array}$ \\
\hline $\begin{array}{l}\text { Dr. Hafiz Amjad Hussain } \\
\text { Senior Registrar, Medicine, DHQ } \\
\text { Hospital, Faisalabad Pakistan }\end{array}$ & Proof Reading \\
\hline $\begin{array}{l}\text { Dr. Umair Ahmed } \\
\text { Senior Registrar, Medicine, Allied } \\
\text { Hospital, Faisalabad Pakistan }\end{array}$ & Study \\
\hline $\begin{array}{l}\text { Dr. Amin Anjum } \\
\text { Assistant Professor of Medicine, } \\
\text { Faisalabad Medical University, } \\
\text { Faisalabad Pakistan }\end{array}$ & References Collection \\
\hline
\end{tabular}

